\title{
Jack MacDougall
}

Professor Jack MacDougall, who died on 31 st January 2000, qualified in dentistry and medicine in 1934-5, obtaining the conjoint diplomas of the Scottish Royal Colleges. During the war he served in the Dental Branch of the RAF at both Millfield and at Lossiemouth. It was while he was in practice in Glasgow that he became a visiting surgeon at the Glasgow Dental Hospital and School, and in 1955 he embarked on a fulltime academic and hospital career. In 1964 he became Professor of Dental Surgery in the University of Glasgow, succeeding Professor James Aitchison - a post he held until his retirement in 1976.

He was a real all rounder. He had broad perspectives in life in general, in sport and in his chosen career of dentistry, to which he brought a rare combination of practical and caring skills and academic and administrative abilities. He had a great interest in people and he was a superb administrator. He enjoyed the challenge of administration in university and NHS hospital affairs and with his clear mind and vision was constantly seeking improvements in education and clinical practice. He was adept at solving problems and would move swiftly to the heart of issues - leaving everyone wondering why they had seen such difficulties in the first place.

Professor Jack MacDougall will be particularly remembered for two important achievements in relation to postgraduate dental education. Firstly, in 1967 his vision and leadership in establishing, with the late Professor Tom White, the Fellowship in Dental Surgery of the Royal College of Physicians and Surgeons of Glasgow. He was a most successful first Convener of the Dental Council. Secondly, for his interest in and encouragement of young graduates and future consultants and specialists where he devised new rotational training schemes which served as a blueprint for national programmes of training.

He took a keen interest in sport. A fine footballer in his youth, he represented Glasgow schools in 1927 and later played for Kilmarnock FC. He played golf regularly at East Renfrewshire, where he was a former club captain and then latterly at West Kilbride.

Many Glasgow graduates will remember

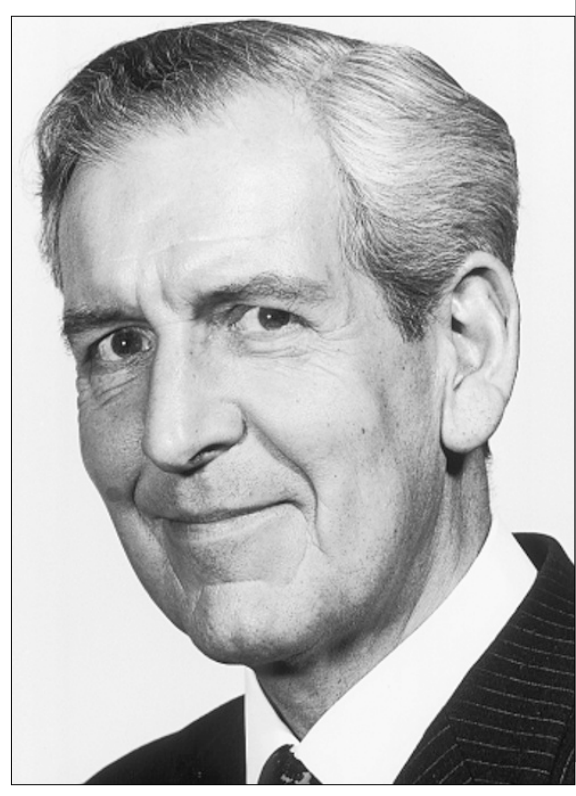

his help and advice and the fine example he set. Those who worked with him will feel privileged to have known him.

Marion, his first wife, died in 1986. He is survived by his two daughters and one son and his second wife Dorothy and her family.

D. $M$.

\section{James W. White}

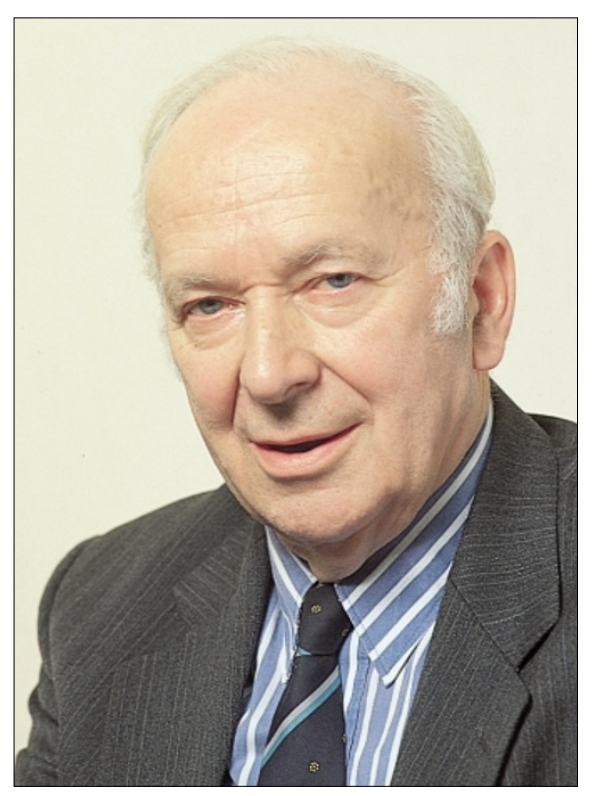

Jamie White was born in Bermondsey, London on 16 November 1927. He was educated at Brentwood School and the London Hospital Dental School where he gained his dental qualification in 1951. His National Service was in the Royal Army Dental Corps.
He worked in hospital posts at the London and St Bartholomews hospitals and was an honorary assistant to Professor A.E.W. Miles in the Odontological Museum at the Royal College of Surgeons in London. He spent two years as a registrar at Dundee Dental Hospital. It was in Scotland that he met his wife Janet, who sadly died in 1998.

In 1959 he joined a practice in Braintree, Essex as a partner. He continued to take an active interest in the profession. He was an examiner for the Dental Surgery Assistants Board, and in 1968 he was appointed as the first Postgraduate Dental Tutor at the Medical Academic Unit at the Chelmsford and Essex Hospital. He also served as a trustee of the Chelmsford Medical Education and Research Trust, supporting postgraduate education for local doctors and dentists. In 1973 he became sole owner and principal of the Braintree practice on his partner's retiral. In 1979 he was awarded the Membership in General Dental Surgery of the Royal College of Surgeons. He also served on the board of examiners for the MGDS for six years. He was a lifelong member of the BDA.
Jamie pursued many interests, he had a great love and knowledge of horses, and rode well. He was a familiar sight in the lanes on his bay mare. He was an expert on horse bits - lorinery, and he taught on a lorinery course in Hackney for the past 12 years. He was a member of the Worshipful Company of Loriners in the City of London, and was Master of the Company in 1976.

He was a keen sailor, and built his boat, which he sailed in the Blackwater estuary. Locally he served for fifteen years on Great Leighs Church Council, he was also an active member of the Leighs Protection Society and a governor of Braintree High School. In the City of London he was a Common Councilor for Cornhill Ward, and he had recently been elected as Chairman of the Libraries Committee, and as a Governor of the Museum of London.

Jamie had three daughters; Catherine who is also a dentist, Caroline and Marion. He was also very proud of his five grandchildren. We extend our deepest sympathy to them all.

C. W. and A. F. 